\title{
NEW VIRUS DISEASES OF PLANTS IN PORTO RICO
}

\author{
MELVILLE T. CoOK
}

During the past year six previously unreported virus diseases have been studied by the writer but some of them had been observed previous to this time. Descriptions are published at this time for the purpose of record and the convenience of the workers.

The mosaic of Crotalaria striata DC, is becoming quite abundant in Porto Rico. The patterns are well defined mosaies of dark and light green in which either color may predominate. In some cases the leaves are almost entirely light green or yellow. Oceasionally plants are dwarfed by the disease. Severely diseased plants produce few or no seeds. Te'sts with seeds from diseased plants have thus far given healthy plants. Field observations indicate that the discase is carried by insects. Well advanced plants that have not shown symptoms of the disease frequently develop the disease in the new growths. The writer has demonstrated that the disease can be transmitted by inoculation with juice from diseased plants.

The mosaic of Commelina longicaulis Jaecl., was fir'st found on the little island of Vieques. This plant grows as a weed in many of the West Indies. The symptoms are rather large chlorotic aret's, sometimes forming rings. The infected plants are as vigorous as the healthy and the symptoms do not appear unless the plants are making a vigorous growth. The symptoms disappear during periods of dry weather.

What appears to be a virus chisease of Carica papaya L. attacked the plants in the Station grounds a few years ago but the gardener destroyed the plants before the writer conld make a study of them. This or a similar disease was later described by Dr. R. Ciferri of Santo Domingo as "curly leaf" but he wa's uncertain as to the cause. My histological studies indicate that it is a virus disease. The young leaves hecome more or less curled and in severe cases, this curling presists throughont the life of the plant. The lower leaves become yellow and fall. One or both symptoms may appear on the plants. Sometimes; all the older leaves fall, leaving a cluster or rosette of leave's at the apex. In severe case's the fruits are reduced in number and size.

Abutilon hirtum (Lam.) Sweet, is a wild speeies of Malvacene which shows a high percentage of diseased plants. The patterns 
vary and the chlorotic areas are yellowish or white. The diseased plants are usually smaller than the healthy plants but many of them are full sized and do not appear to be injured by the disease. The diseased plants produce very few seeds. The writer has colleeted and sown a considerable member of these seeds but thus far the seedlings have not shtown any symptoms of the disease. Field observation show that it spreads from plant to plant and indicate that it is carried by insects. This disease is interesting because of the lact that the variegated Abutilons which became so popular as ornainentals in Europe about seventy years ago are said to have come from the West Indies.

A mosaic disease is very common on Sida carpinifolia $\mathrm{L}$. and S. rhombifolia. L. and has the same characteristics as the one on $A$. hirtum and may be due to the same virus. This disease is abundant and the diseased and healthy plants may be found growing in contact.

Andenoropzium gossypifolium (L.) Pohl. is subject to mosaic which is very common. The chlorotic areas are numerous, variable in size and form, frequently coalescing but very rarely eovering the entire leaf. The chlorotic areas grow slower than the green parts which results in slight puckerings.

Ipomoea nil (L.) Roth, which grows abundantly throughout the island is subject to a mosaic which varies from a slight mottling with yellowish or almost white areas to leares which do now show any of the green color.

Mr. Francisco Seín, Jr., Assistant Entomologist has called the attention of the writer to a mottling of the mulberry leaves. This disease appears as a mottling very characteristic of the mosaic. A second patter which appears as zigzag lines across the leaves may be due to the same cause. Mr. Seín tells me that he has transmitted this disease by means of scions.

\section{EXPLANATIOIN OF FIGURES}

Figure 1.- Fealthy and Mosaic leaves of Crolataria striata.

Figure 2.-Mosaic leaves of Commelina longicaulis.

Figures $3 \& 4$-Carica papaya plant showing effect of a virus disease.

Figure 5.-Advanced stage of Carica papaya with a virus disease.

Figure 6.-A very small plant of Carica papaya dwarfed as a result of a virus disease. Note the normal plants on either side.

Figure 7.-Diseased leaf of C. papaya.

Figure 8.-Healthy leaf of C. papaya. 
Plate No.-. One healthy and seven mosaic leaves of Abutilin kirtum.

Figure 9.-Mo'saic leaves of Sida carpinifolia.

Figure 10.-Mosaic leaf of Andenoropium gossypifolium.

Figure 11.-Mosaic leaf of Ipomoea nil.

$$
0-\mathrm{O}-0
$$


PLATE XV.
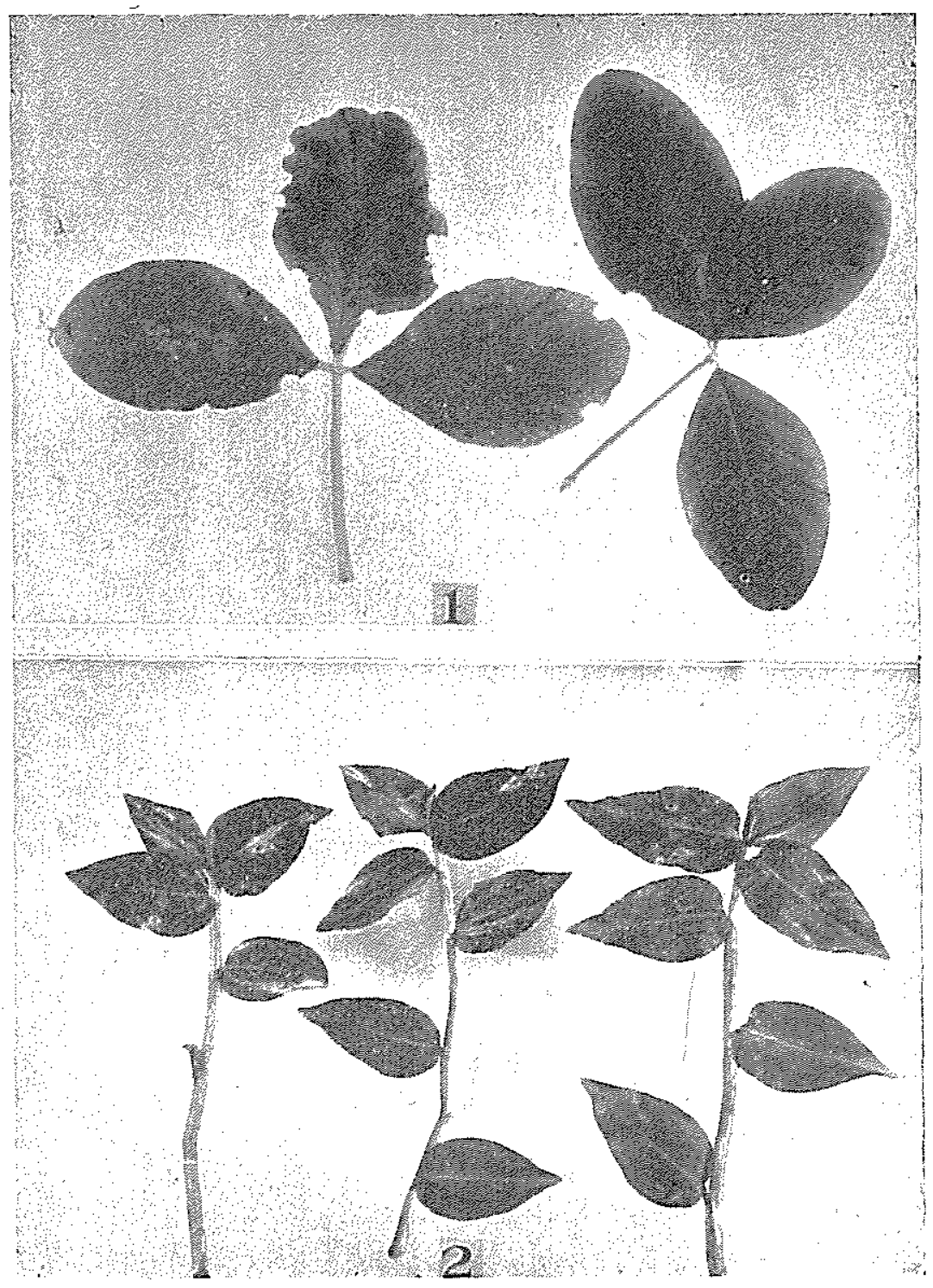
PLATE XVI.

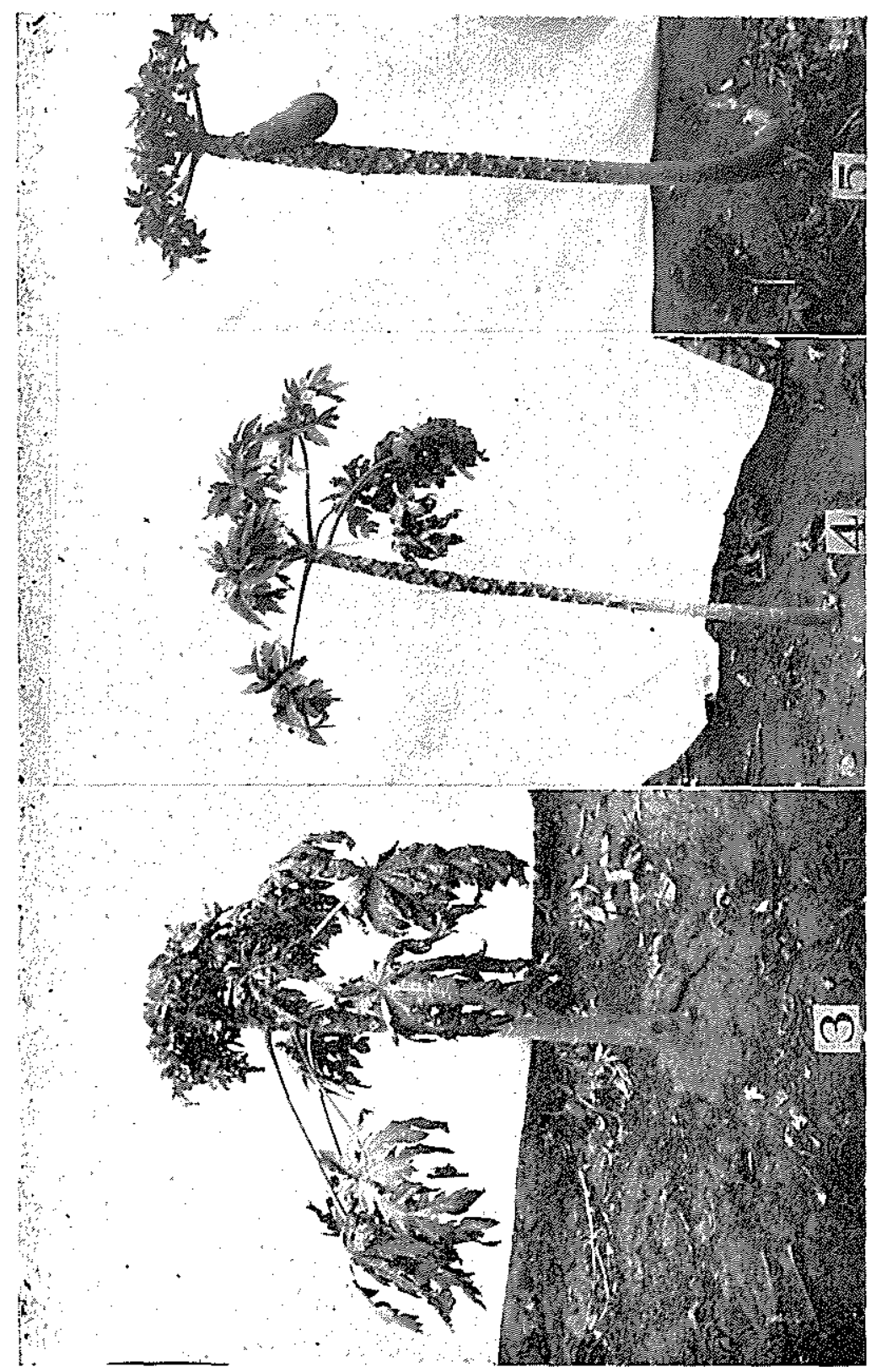




\section{PLATE XVII.}

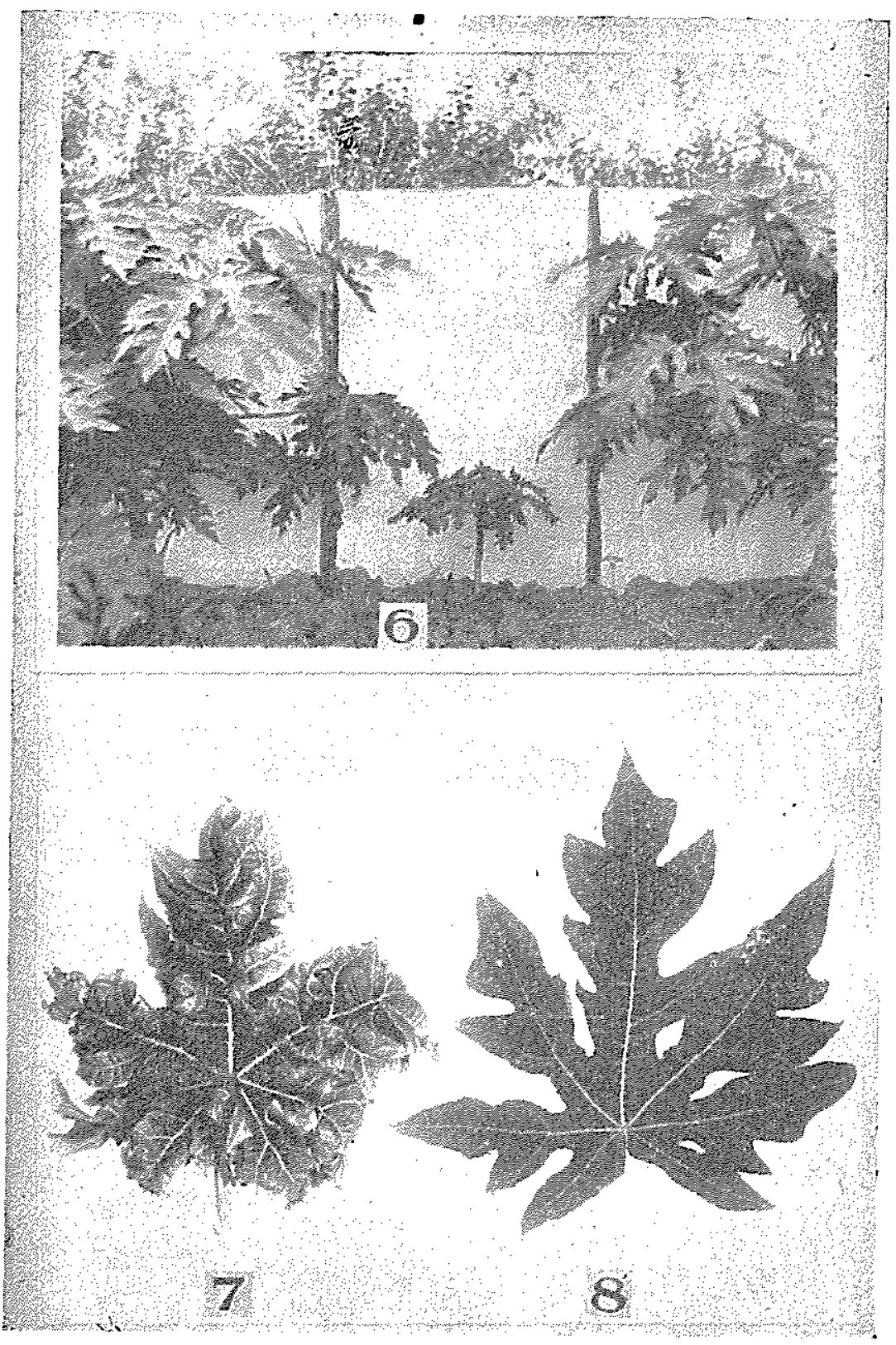




\section{PLATE XVIII.}

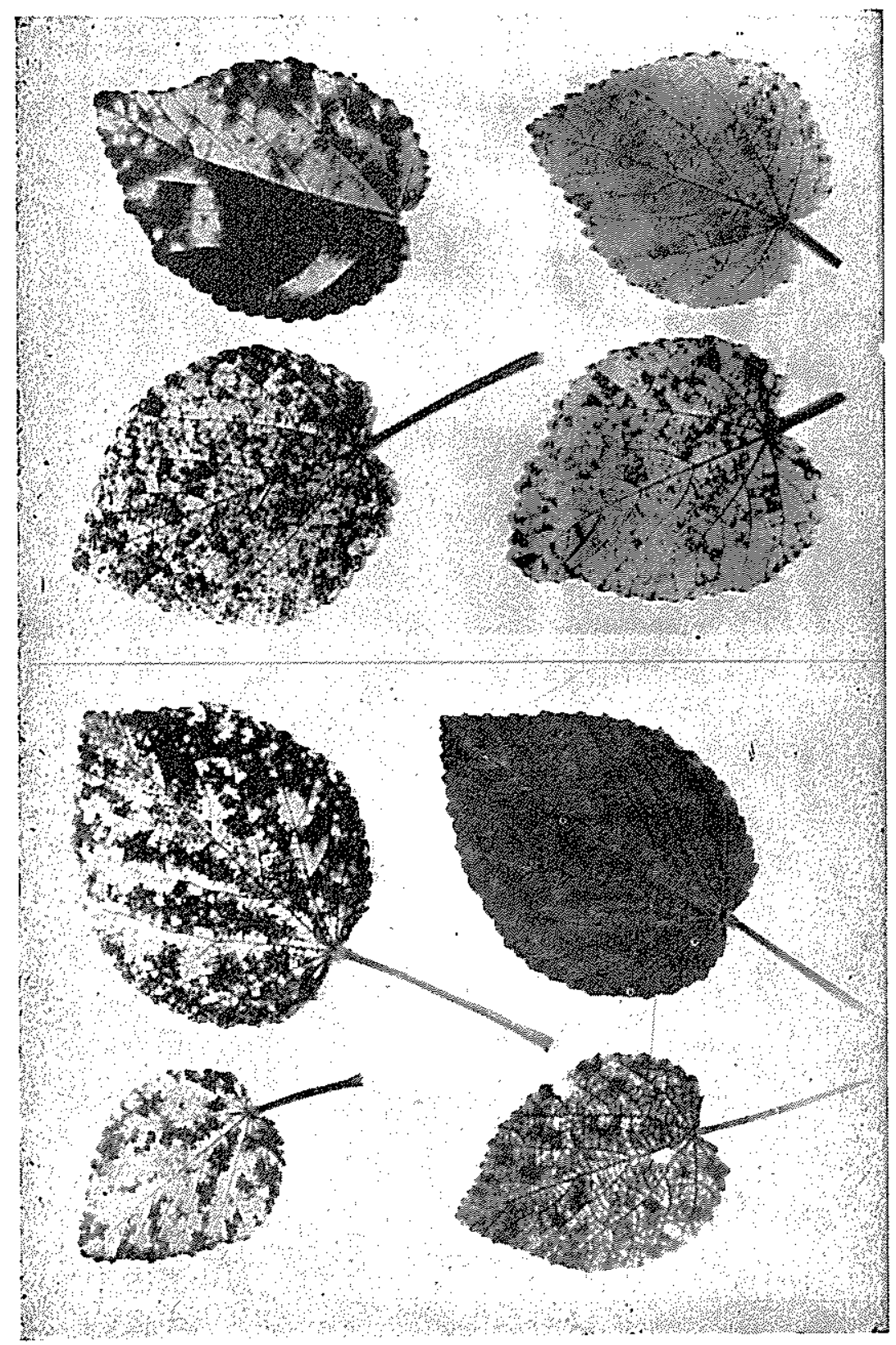


PLATE XIX.

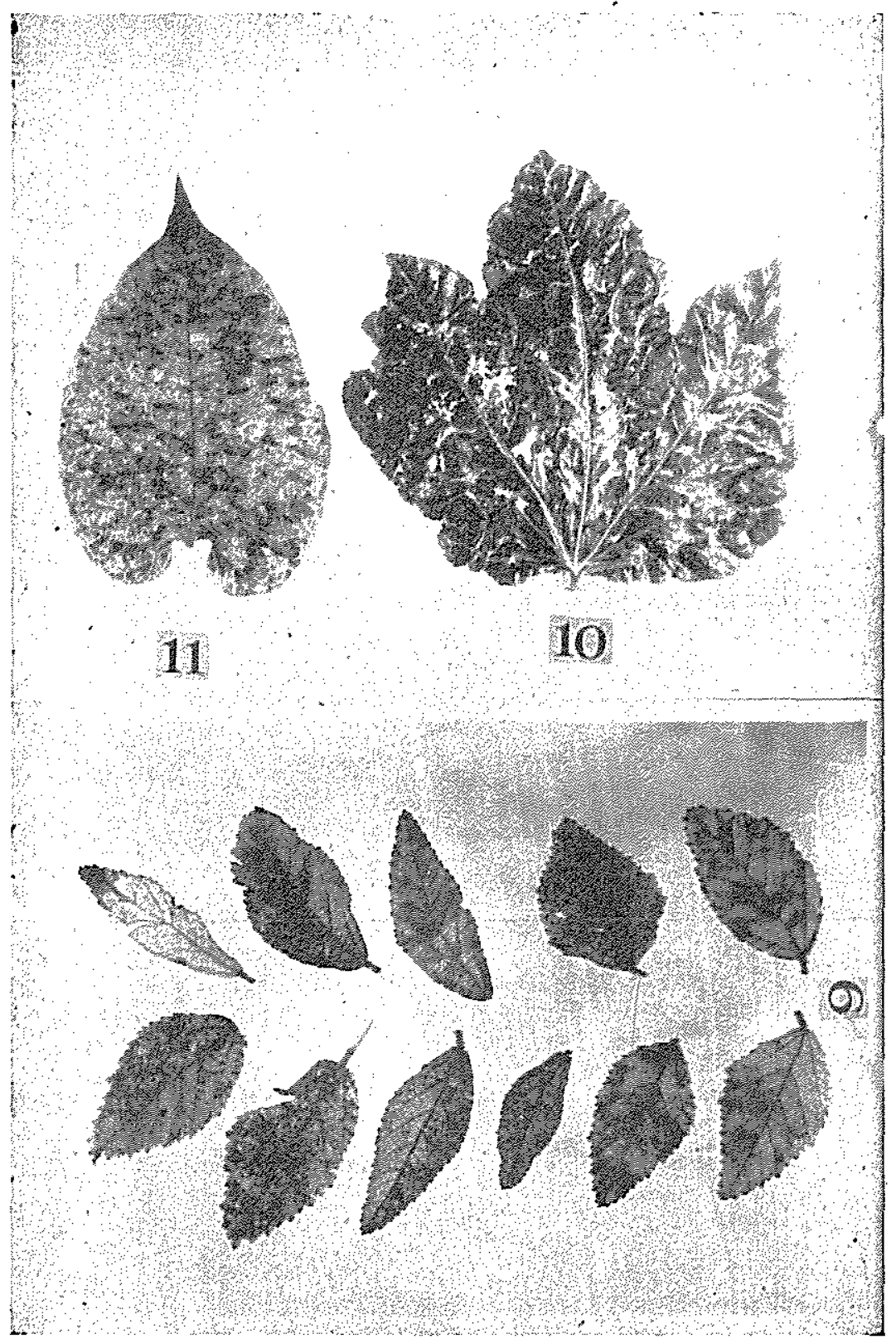

